\title{
Is there a link between surgically treated arachnoid cysts and the development of idiopathic intracranial hypertension?
}

\author{
Ulrika Sandvik* \\ Department of Clinical Neuroscience, Division of Neurosurgery, Karolinska Institutet, Karolinska University Hospital, Stockholm, Sweden
}

Arachnoid cysts are common radiological findings, often identified in childhood. The cyst have been linked to various symptoms, mainly dependent on the location. Generally, conservative treatment has been advocated for the adult population whereas many authors advocate a more aggressive approach for pediatric patients. Indications for surgery have been enlargement of cyst, intracranial hypertension, abnormal skull growth, hemorrhage, bony asymmetry, aggravation of symptoms or abnormality/ worsening of serial neuropsychological tests [1-5]. The frequency of arachnoid cysts has been reported to be as high as 2,6\% in children who have undergone cerebral imaging [6].

Most arachnoid cysts are believed to be congenital whereas a small percentage is believed to have formed from trauma, inflammation or bleeding $[7,8]$.

Several theories regarding the formation of arachnoid cysts exist. A ball-valve theory has been proposed regarding enlargement of cysts. According to this theory the differential pulsatile movement vectors of the cyst and cerebrospinal fluid (CSF), fluid production by the cells lining the walls of the cysts, fluid shift via osmotic gradient, fluid movements secondary to pulsations of the veins could cause an enlargement of the cyst $[7,9]$. Other studies have contradicted this by claiming that protein count of cysts and CSF is similar [10].

In a recent review of our own experiences (unpublished data) we identified two cases of idiopathic intracranial hypertension (IIH) developing a few years after an initially successful treatment of arachnoid cysts. Only a few papers have so far reported idiopathic intracranial hypertension appearing in children who have undergone surgical treatment of arachnoid cysts.

The diagnostic criteria of IIH include symptoms and signs of elevated intracranial pressure; normal findings on neuroimaging, excluding nonspecific findings of increased intracranial pressure; and increased CSF pressure with a normal composition [11].

The relationship between arachnoid cysts and IIH has not been much researched although it has been described in a few cases. The IIH has always been described to occur after (1-12 years) the surgical treatment of the arachnoid cyst $[12,13]$. One publication describes IIH in connection to arachnoid cysts in the Fallopian canal [14]. A case report dated back to 1996 describes IIH and posterior fossa arachnoid cyst [15] treated with a cystoperitoneal shunt.

One suggested link between the two conditions has been that the diversion of cystic and subdural CSF into the basal cistern might cause decompensation of a preexisting compensated CSF circulation $[12,16]$.
It has also been suggested that the cyst fluid might be different (secreted from the cyst lining cells) from the CSF and hence could affect the circulation of CSF [10]. Other possible causes could be the development of venous thrombosis or stenosis, slit ventricles (due to periventricular or ependymal gliosis), decreased cyst wall compliance after surgery or an imbalance between cyst fluid production and resorption [12].

\section{References}

1. Lee JY, Kim JW, Phi JH, Kim SK, Cho BK, et al. (2012) Enlarging arachnoid cyst: a false alarm for infants. Childs Nerv Syst 28: 1203-1211. [Crossref]

2. Choi JW, Ji Yeoun Lee, Ji Hoon Phi, Seung-Ki Kim, Kyu-Chang Wanget (2015) Stricter indications are recommended for fenestration surgery in intracranial arachnoid cysts of children. Childs Nerv Syst 31: 77-86. [Crossref]

3. Kimiwada T, Toshiaki Hayashi, Ayumi Narisawa, Reizo Shirane, Teiji Tominaga (2015) Shunt placement after cyst fenestration for middle cranial fossa arachnoid cysts in children. Journal of Neurosurgery: Pediatrics 16: 533-539. [Crossref]

4. Wang Y, Wang F, Yu M, Wang W (2015) Clinical and radiological outcomes of surgical treatment for symptomatic arachnoid cysts in adults. Journal of Clinical Neuroscience 22: 1456-1461. [Crossref]

5. Huang JH, Mei WZ, Chen Y, Chen JW, Lin ZX (2015) Analysis on clinical characteristics of intracranial Arachnoid Cysts in 488 pediatric cases. Int J Clin Exp Med 8: 18343-18350. [Crossref]

6. Al-Holou WN, Yew AY, Boomsaad ZE, Garton HJ, Muraszko KM, et al. (2010) Prevalence and natural history of arachnoid cysts in children. J Neurosurg Pediatr 5: 578-585. [Crossref]

7. Fulkerson DH, Vogel TD, Baker AA, Patel NB, Ackerman LL, et al. (2011) Cystventricle stent as primary or salvage treatment for posterior fossa arachnoid cysts. $J$ Neurosurg Pediatr 7: 549-556. [Crossref]

8. 8. Li L, Zhang Y, Li Y, Zhai X, Zhou Y, Liang Pe (2013) The clinical classification and treatment of middle cranial fossa arachnoid cysts in children. Clin Neurol Neurosurg 115: 411-418. [Crossref]

9. Cincu R, A Agrawal, J Eiras (2007) Intracranial arachnoid cysts: current concepts and treatment alternatives. Clin Neurol Neurosurg 109: 837-843. [Crossref]

10. Berle M, Ann Cathrine Kroksveen, Hilde Garberg, Mads Aarhus, Øystein Ariansen Haaland, et al. (2013) Quantitative proteomics comparison of arachnoid cyst fluid and cerebrospinal fluid collected perioperatively from arachnoid cyst patients. Fluids Barriers CNS 10: 17. [Crossref]

11. Quintana LM (2013) An Unresolved Relationship —-Treated Arachnoid Cysts and Idiopathic Intracranial Hypertension. World Neurosurgery 80: 80-82. [Crossref]

Correspondence to: Ulrika Sandvik, Department of Clinical Neuroscience, Division of Neurosurgery, Karolinska Institutet, Karolinska University Hospital, Stockholm, Sweden, E-mail: ulrika.sandvik@ki.se

Received: November 28, 2016; Accepted: December 19, 2016; Published: December 22, 2016 
12. Kaliaperumal C, B O'Connor, C Marks (2013) Development of Intracranial Hypertension After Surgical Management of Intracranial Arachnoid Cyst: Report of Three Cases and Review of the Literature. World Neurosurgery 80: 222.e1-222.e4. [Crossref]

13. Lindner U, Bubl B, Steudel WI, Papanagiotou P, Käsmann-Kellner B, et al. (2009) Increased Intracranial Pressure Caused by Non-Space-Occupying Arachnoid Cysts: Report of Two Patients. Neuropediatrics 40: 89-91. [Crossref]

14. Sagardoy T, De Mones E, Bonnard D, Darrouzet V, Franco-Vidal V (2016) Arachnoid cyst of the Fallopian canal and geniculate ganglion area: our experience of 9 cases. Clin Otolaryngol. [Crossref]

15. Cabral ND, Nitrini R, Plese JP (1996) [Arachnoid cyst and pseudotumor cerebri: case report]. Arq Neuropsiquiatr 54: 304-308. [Crossref]

16. Schulz M, Kimura T, Akiyama O, Shimoji K, Spors B, et al. (2015) Endoscopic and Microsurgical Treatment of Sylvian Fissure Arachnoid Cysts-Clinical and Radiological Outcome. World Neurosurgery 84: 327-336. [Crossref]

Copyright: (2016 Sandvik U. This is an open-access article distributed under the terms of the Creative Commons Attribution License, which permits unrestricted use, distribution, and reproduction in any medium, provided the original author and source are credited. 